value was normal or low in eight. (The frequently raised serum gastrin concentration in the mucous cell type merely reflects hypochlorhydria or occasionally antral disease, and does not necessarily imply a causative role for gastrin.) The rarity of antral disease makes duodenogastric reflux an unlikely cause. The recent discovery of high gastric luminal concentrations of prostaglandin $\mathrm{E}_{2}$ in Menetrier's disease may be aetiologically important, especially since this agent is known to inhibit secretion of gastric acid and increase mucosal permeability.

The symptoms of hyperplastic gastropathy are common to the different variants and have been documented by Fieber and Rickert. ${ }^{2}$ The characteristic features are epigastric pain $(78 \%)$, vomiting (48\%), weight loss (41\%), peripheral oedema (40\%), and bleeding (27\%). Appropriate investigations include barium meal, gastroscopy, gastric acid studies, serum albumin estimation, protein clearance studies, and serum gastrin measurement. The diagnosis rests on histological examination of a full thickness biopsy specimen of the stomach taken at laparotomy, or possibly by using an endoscopic diathermy snare. Because of the mucosal thickness, normal endoscopic biopsy provides too shallow a sample for adequate assessment.

The relation between hyperplastic gastropathy and gastric carcinoma is controversial. ${ }^{1}$ There are at least 16 reports of carcinoma in association with histologically proved Menetrier's disease, and in four of these the gastropathy was diagnosed two to 14 years before the carcinoma appeared..$^{7-11}$ The incidence of two premalignant conditions (intestinal metaplasia and gastric adenomatous polyps) in hyperplastic gastropathy may provide the pathological link with gastric cancer, and patients who have these features should be observed closely. The incidence of malignancy in hyperplastic gastropathy is probably no greater than $5 \%$.

The inadequacy of treatment of symptomatic hyperplastic gastropathy is shown by the number of methods reported. Diet, antacids, anticholinergic drugs, prednisone, trimetaphan, $\mathrm{H}_{2}$ receptor blockade, and prostaglandins have given equivocal results. ${ }^{2}$ Surgery is reserved for diagnostic biopsy, intractable pain, protein loss, haemorrhage, pyloric obstruction, or carcinoma. Partial gastrectomy is the commonest procedure and has the advantage of reducing the mucosal area and the risk of malignancy. While incomplete excision may be followed by remission of residual disease, the risk of anastomotic leakage through diseased tissue is considerable. Total gastrectomy should be reserved for complicated proximal disease, for extensive disease, or for carcinoma. For localised disease mucosal resection is an attractive procedure, ${ }^{12}$ but more specific treatment awaits elucidation of the cause of this rare and interesting condition.

J N L SimSON

Senior Registrar,

Department of Surgery,

Guy's Hospital,

London SE1 9RT

I Cooper BT, Chadwick VS. Menetrier's disease. In: Baron JH, Moody FG, eds. Gastroenterology. 1 The foregut. London: Butterworths, 1981:141-91.

2 Fieber SS, Rickert RR. Hyperplastic gastropathy. Am f Gastroenterol 1981;76:321-9.

3 Reeder MM, Olsted WW, Cooper PH. Large gastric folds, local or widespread. $7 A M A$ 1974;320:272-4.

4 Ming SC. Tumors of the esophagus and stomach. Washington: Armed Forces Institute of Pathology, 973:115-9,153-4.

5 Lawson HH. Primary giant mucosal folds. S Afr f Surg 1975;13:33-42.

6 Burrell M, Avella J, Gryboski J, Ablow R. Transient hypertrophic gastropathy in childhood: a protein-losing gastropathy distinct from Menetrier's disease. Am J Gastroenterol 1979;72: $458-64$

Spellberg MA, Baker L. Gastritis: clinical significance with special emphasis on the tumorsimulating variety. Med Clin North Am 1953;37:41-61.

8 Games AD, Hawk WA, Owens FJ, et al. Hypertrophic gastropathy and carcinoma of the stomach. Report of a case. Gastrointest Endosc 1966;12:29-33.
9 Moeller DD, Dunn GD, Laing RR, Klotz AP. Hypertrophic gastropathy and carcinoma of the tomach. Gastrointest Endosc 1970;16:159-62.

0 Chusid EL, Hirsch RL, Colcher H. Spectrum of hyperplastic gastropathy. Arch Intern Med 1964;114:621-8.

11 Loewenthal von M, Steinitz H, Friedlander E. Gastritis hypertrophica gigantea und Magenkarzinom. Gastroenterologia (Basel) 1960;93:133-44.

12 Park WD. Giant hypertrophic gastritis. Lancet 1956;i:270,751.

\section{Handling cytotoxics}

Concern about the potential hazards of handling cytotoxic drugs is increasing, ${ }^{1-6}$ and, though few dispute the need for care with agents that may cause contact dermatitis, ${ }^{7}$ direct irritation of the skin and mucous membranes, ${ }^{8-12}$ or corneal damage, ${ }^{1314}$ controversy surrounds the mutagenic risks to hospital staff. The Ames test ${ }^{15}$ and its variant ${ }^{16}$ measure mutagenicity by assessing the effect on certain strains of bacteria, usually Salmonella typhimurium or Escherichia coli, of concentrated urine from the exposed person. Falck et al were the first to show mutagenicity in the urine of nurses handling cytotoxic drugs. ${ }^{2}$ Subsequently Staiano et al reported a lack of urine mutagenicity in eight pharmacists and concluded that this was because they handled anticancer drugs carefully. ${ }^{17} \mathrm{~A}$ further study of 10 nurses who routinely gave patients cytotoxic drugs that had been prepared by pharmacists showed no increase in mutagenicity compared with nurses who did not administer these drugs. ${ }^{18}$ Doubts about the relevance of these tests have been raised, however, by reports of increased mutagenicity in the urine of nurses who smoke and handle cytotoxic drugs but not in their nonsmoking counterparts. ${ }^{19} 20$ The results of these assays may also be confounded by dietary factors. ${ }^{21-23}$

Additional evidence on the potential effects of cytotoxic drugs comes from studies of the chromosomes of nurses handling them ${ }^{24-26}$ though the biological importance of this work has been questioned. ${ }^{27} \mathrm{~A}$ more direct method of assessing potential risk may be to measure drug absorption. Jagun et al assayed thioethers, an indicator of absorption of alkylating agents, and reported that concentrations in nurses handling cytotoxic drugs were higher after a five day work spell than after three days' holiday. ${ }^{28}$ Hirst et al found detectable amounts of cyclophosphamide in the urine of nurses who were exposed to the drug, though there was no correlation between the dose handled and the urinary concentration. ${ }^{29}$ Venitt et al failed to detect cisplatin in the urine of nurses and pharmacists routinely handling the drug, ${ }^{23}$ though again this may merely show that the precautions taken in a large cancer centre are effective. ${ }^{6}$ Studies of the air in rooms where cytotoxic drugs are prepared ${ }^{30}$ and in areas close to a horizontal laminar airflow hood ${ }^{31}$ showed detectable amounts of fluorouracil and support the concept that absorption may occur through an aerosol route. Exposure to the waste products of patients undergoing anticancer treatment may represent an additional hazard. ${ }^{32-34}$ Thus Venitt et al, while failing to detect cisplatin in nurses administering the drug, found concentrations of $7 \mathrm{mg} / \mathrm{l}$ in patients' urine. ${ }^{23}$ The results of studies of mutagenicity in nurses handling waste products are awaited.

Although the evidence suggests that hospital staff who prepare and administer cytotoxic drugs are at risk from mutagenicity, it is not conclusive and no increased incidence of cancer has been reported. Nevertheless, recommendations have been made for safe handling of cytotoxic drugs. ${ }^{35-38}$ In Britain this guidance has come from the Health and Safety Executive. ${ }^{36}$ The American Society of Hospital Pharmacists 
has said that without conclusive evidence of need for and effectiveness of protective measures guidelines "will be based to a great extent on professional judgment rather than scientifically established fact."

In the $B M 7$ this week Colls (p 1318) has scrutinised the package inserts of cytotoxic drugs and found that few manufacturers advise on safe ways to handle them. (Personal examination of similar data on other potentially toxic drugs shows a similar lack of advice.5) Although usually only experienced clinicians prescribe cytotoxic drugs, treatment may be given by inexperienced staff, and a package insert warning of potential hazards and giving sources of recommended guidelines for safe handling seems sensible.

The fact that there are recommended guidelines from national organisations ${ }^{3536}$ may place a legal obligation on hospital authorities. ${ }^{39}$ In Britain the Health and Safety at Work Act 1974 states that "the employer has a general duty to make sure that the use, handling, storage, and transportation of articles and substances is safe and no risk to the health of his employees." The Congenital Disabilities (Civil Liability) Act 1976 protects the unborn. While a primary claim by an employee arising from misuse of cytotoxic drugs may be against the employing hospital authority, a subsidiary claim might be made against the manufacturer. ${ }^{39}$ Some manufacturers have issued pamphlets on cytotoxic drug handling, ${ }^{+0+1}$ but most data sheets and package inserts give little such advice.

Ideally, the preparation of intravenous cytotoxic drugs should be carried out only in hospital pharmacies where staff are experienced and safety equipment is available. ${ }^{+2+3}$ As well as improving safety such a system might be more cost effective. ${ }^{43}$ In the United States the process has been taken a step further and commercial drug reconstitution services are available. In Britain at least one health district has negotiated a commercial contract, though it remains to be seen if this approach will be cost effective. ${ }^{+4}$

More research into the dangers associated with handling cytotoxic agents is needed before substantive recommendations for individual drugs can be developed-and employees' apprehension lessened. ${ }^{45}$ The risk to hospital staff needs to be put in perspective, however, for the incidence of second malignancies in patients receiving pharmacological doses of cytotoxic drugs is low. Reimer et al found only 13 cases of acute non-lymphocytic leukaemia in about 4000 women who had received alkylating agents for ovarian carcinoma. ${ }^{46}$ Twelve of the 13 patients had had treatment for over two years. Meanwhile, the best that drug manufacturers can do is to repeat the guidelines that have already been proposed. They may not be ideal, but they emphasise that care is required.

C J Williams

Senior Lecturer,

CRC Medical Oncology Unit,

Southampton General Hospital,

Southampton SO9 4XY

1 Anonymous. Occupational hazards of cytostatic agents. Hospital pharmacist's discussions [Editorial]. Pharmaceutical fournal 1977;219:335.

2 Falck K, Grohn P, Sorsa $M$, et al. Mutagenicity in urine of nurses handling cytostatic agents. Lancet 1979;i:1250-1.

3 Knowles RS, Virden JE. Handling of injectable antineoplastic agents. Br Med f 1980;ii:589-91.

4 Harrison BR. Developing guidelines for working with antineoplastic drugs. Am f Hosp Pharm 1981;38: 1686-93.

5 Jacobs JY. Work hazards from drug handling. Pharmaceutical Journal 1984;233:195-6.

6 American Society of Hospital Pharmacists. Technical assistance bulletin on handling cytotoxic drugs in hospital. Am J Hosp Pharm 1985;42:131-7.

7 Reich BD, Bachur NR. Contact dermatitis associated with adriamycin (NSC-123127) and daunorubicin (NSC-82151). Cancer Chemotherapy Reports 1975;59:677-8.

8 Dreizen S, Bodey GP, Rodriguez V, McCredie KB. Cutaneous complications of cancer chemotherapy. Postgrad Med 1975;58:150-7.

9 Dreizen S, Bodey GP, Rodriguez V. Oral complications of cancer chemotherapy. Postgrad Med 1975;58:75-82.
10 Levantine A, Almeyda J. Cutaneous reactions to cytostatic agents. Br f Dermatol 1974;90:239-42. 11 McLendon BF, Bron AJ. Corneal toxicity from vinblastine solution. Br f Ophthalmol 1978;62: $97-9$

12 Pedersen B, Bramsen T. Accidental injury to the cornea by podophyllin. Ugeskr Laeger 1980;142:452-3.

13 Connor TH, Laidlaw JL, Theiss JC, et al. Permeability of latex and polyvinylchloride gloves to carmustinc. Am 7 Hosp Pharm 1984;41:676-9.

4 Laidlaw JL, Connor TH, Theiss JC, et al. Permeability of latex and polyvinylchloride gloves to 20 antineoplastic drugs. Am 7 Hosp Pharm 1984;41:2618-23.

15 Ames BN, McCann J, Yamasaki E. Methods for detecting carcinogens and mutagens with the salmonella/mammalian-microsome mutagenicity test. Mutat Res 1975;31:347-64

16 Green MH, Muriel WJ. Mutagen testing using trp ${ }^{\dagger}$ reversion in Escherichia coli. Mutat Res 1976;38:3-32

17 Staiano N, Gadlelli JG, Adamson RH, I horgeirsson SS. Lack of mutagenic activity in urine from hospital pharmacists admixing antitumour drugs. Lancet 1981;i:615-6.

18 Hoffman DM. Lack of urine mutagenicity of nurses administering pharmacy prepared doses of antincoplastic agents. American fournal of Intravenous Theraps and Clinical Nutrition 1983;10: $30-1$.

19 Bos RP, Leenaars AO, Theuws JLG, Henderson PTh. Mutagenicity of urine from nurses handling cytostatic drugs. Int Arch Occup Environ Health 1982;50:359-69.

20 Signori O, Fishman D, Signori E, Palchandhuri S. Observationson the occupational exposure of health care workers to chemotherapeutic agents. Proceedings of American Society of Clinical Oncology 1985;4:23.

21 Gibson JF, Bakter PJ, Hedworth-Witty RB, Gompertz D. Urinary mutagenicity assays: problems arising from the presence of histadine-associated growth factors in XAD-2-prepared urine concentrates; particular relevance to assays carried out using bacterial fluctuation tests Carcinogenesis 1983;4:1471-6.

22 Gibson JF, Gompert\% D, Hedworth-Wittey RB. Mutagenicity of urine from nurses handling cytotoxic drugs. Lancet 1984; i: 100-1.

23 Venitt S, Crofton-Sleigh C, Hunt J, et al. Monitoring exposure of nursing and pharmacy personnel to cytotoxic drugs: urinary mutation assays and urinary platinum as markers of absorption. Lancet 1984;: $: 74-6$

24 Norppa $\mathrm{H}$, Sorsa $M$, Vainio $\mathrm{H}$, et al. Increased sister chromatid exchange frequencies in lymphocytes of nurses handling cytostatic drugs. Scand 7 Work Environ Health 1980;6:299-301.

25 Waksvik $\mathrm{H}$, Klepp D, Brogger A. Chromosome analyses of nurses handling cytostatic agents. Cancer Treat Rep 1981;65:607-10.

26 Nikula E, Kiviniittyk K, Leisti J, et al. Chromosome aberrations in lymphocytes of nurses handling cytostatic agents. Scand $\mathcal{Y}$ Work Environ Health 1984;10:71-4.

27 Anonymous. How real is the hazard [Editorial]. Lancet 1984, i: 203.

28 Jagun $\mathrm{O}$, Ryan $\mathrm{M}$, Waldrom $\mathrm{HA}$. Urinary thioether excretion in nurses handling cytotoxic drugs. Lancet 1982;ii:443-4.

29 Hirst M, Tse S, Mills DG, et al. Occupational exposure to cyclophosphamide. Lancet 1984; 186-8

30 Neal A de W, Wadden RA, Chiou WL. Exposure of hospital workers to airborne antineoplastic agents. Am f Hosp Pharm 1983;40:597-601.

31 Kleinberg ML, Quinn MJ. Airborne drug levels in a laminar flow hood. Am $\mathcal{J}$ Hosp Pharm $1981 ; 38: 1301-3$.

32 Wilson SJ. Safe disposal of some commonly used injectable antineoplastic drugs. $\mathcal{J}$ Clin Hosp Pharm 1983;8:245-99.

33 Vaccari PL, Tonat K, DeChristoforo R, et al. Disposal of antineoplastic wastes at the National Institutes of Health. Am 7 Hosp Pharm 1984;41:87-93.

34 Harris J, Dodds LJ. Handling waste from patients receiving cytotoxic drugs. Pharmaceutical fournal 1985;235:289-91.

35 National Study Commission on Cytotoxic Exposure. Recommendations for handling cytotoxic agents. Providence, RI: NSCCE, 1983.

36 Health and Safety Executive. Precautions for the safe handling of cytotoxic drugs. London: Health and Safety Executive, 1983. (Guidance note MS21.)

37 Anonymous. Guidelines for the handling of cytotoxic drugs [Editorial]. Pharmaceutical fournal 1983;230:230-1.

38 Davis MR. Guidelines for the handling of cytotoxic drugs in pharmacy departments and hospital wards: the Society of Hospital Pharmacists of Australia's speciality practice committee on parenteral services. Hosp Pharm 1981;16:17-20.

39 Provost GJ. Legal issues associated with the handling of cytotoxic drugs. Am f Hosp Pharm 1984;41:1115-21.

40 Boots Company Ltd. Safety sheet: mustine hydrochloride BP. Nottingham: Boots Co Ltd, 1978. 41 Lederle Laboratories. Handling cytotoxic drugs: a practical guide. Gosport: Lederle Laboratories, 1985.

42 Anderson M, Brassington D, Bolger J. Development and operation of a pharmacy-based intravenous cytotoxic reconstitution service. Br Med I 1983;286:32-5.

43 Oakley PA, Reeves E. The value of a centralised reconstitution service. Pharmaceutical fournal 1984;232:391-2.

44 Anonymous. On-site cytotoxic service: a first for Travenol [Editorial]. Pharmaceutical fournal 1984;233:726-7.

45 Moore TD, Hale KM, Cortese LM, et al. Managing employee apprehension toward handling cytotoxic drugs. Am $\mathcal{J}$ Hosp Pharm 1985;42:826-31.

46 Reimer RR, Hoover R, Fraumeni JF, Young RC. Acute leukemia after alkylating-agent therapy of ovarian carcinoma. N Engl f Med 1977;297:177-81.

\section{Honorary injustice for medical teachers}

University clinical staff are a beleaguered group of doctors. The government has cut university funds by $15 \%$ since 1981 , which has resulted in lost jobs and reduced research activities; it has trimmed the Medical Research Council's budget; and now it is stalling over providing the money necessary to restore the pay of these "honorary" National Health Service doctors to its traditional position of parity with the pay of NHS clinicians.

Earlier this year Professor C J Dickinson gave a graphic

\section{ס

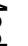

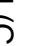 ,

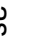 5 W (a) 